\title{
STUDIES ON THE AEREOBIOLOGY OF PUERTO RICO
}

\author{
RAFAEL $\backslash$ A. TORO'
}

The vast and complex conglomerate of living organisms known as the biota of the air is made up of bacteria, fungi and mites. A second important group, the products of living organisms, are insect emanations, pollen grains, and the minute particles of furs, linen, feathers, animal danders, etc. which form legion in house dust. Of the biota the more abundant in the Puerto Rico air are the fungi. The present paper deals with this group.

For the last three years the writer has been studying the fungi of the air with the object of discovering if there is any relation between them and the numerous cases of nasal allergy occuring in the Island. Several facts point toward a close correlation between fungi and nasal allergy. This subject will be dealt with in a forthcoming paper.

All the fungi were obtained by exposing plates of Sabouraud's media for five minutes, in different localities, especially in the residences of asthmatic individuals. Each fungus was then grown separately in test tubes and set aside for determination. The species herein reported are those that were obtained with greater frequency. Slides coated with Brandt's glycerinjelly were also exposed for twenty four hours, in order to obtain a daily sample of the air content and correlate the study with the quantitative and qualitative data obtained in the cultures.

The number of species of fungi herein reported is 24 . Those marked with an asterisk are new to Puerto Rico, while the new species or combinations appear in bold faced type.

I wish to express my appreciation to Dr. Manuel Pila of Ponce, Puerto Rico, whose unaltered inspiration has guided this work and whose unfailing advice has been most useful. Thanks are also due to Miss Marie Betzner Morrow, of the Bacteriology Department, University of Texas, for her help in the determination of some of the fungi here mentioned.

\section{CHAETOMIACEAE}

1. Chaetomium globosum Kunze \& Schm.

Perithecia about $300 \mu$ in diameter, olivaceous, clothed with slender hairs; asci clavate.

Isolated from the awnings in the residence of Mr. C. E. Chardón, Mayaguez.

${ }^{1}$ Contribution No. 14 from the Department of Biology, School of Science, College of Agriculture and Mechanic Arts, University of Puerto Rico. Published with the authorization of the Dean. 


\section{PHOMACEAE}

\section{Coniothyrina ponceana sp. nov.}

Pycnidiis globuloso-depressis, membranaceis, sparsis, superficialibus, nigris, contexto fuligineo; myceliis septatis fuscis, sporulis sphaeroides, fuligineis, intense olivaceis, interdum 1-guttatis; chlamydosporiis intercalaribus fuscis.

In solutionibus cultum. Prope Ponce, Puerto Rico. Oct. 1945.

Mycelium olivaceous, pellucid, septate, branched, $3 \mu$ thick; ropy hyphae 4-6 $\mu$ wide and thick walled, darker in color; pycnidia round, black, without ostiole, membranaceous, $400-600 \mu$ in diameter; chlamydospores intercalary, almost round, thick-walled, immersed in the substratum, in chains, dark-brown, 6-8 $\mu$ in diameter; conidia round, olivaceous, with oil drops, smooth, 4-6 $\mu$ in diameter.

The genus Coniothyrina was established by Sydow (Ann. Myc. 10: 233, 1912) to replace Coniothyrella Speg.; which was untenable because of priority. As defined it differs from Coniothyrium Corda in possessing superficial pycnidia without ostiola.

Although we have placed this fungus under the above genus we do it with some degree of hesitancy. The growth in Sabouraud's medium is typically penicelloid, the mycelium presents the same type of intercalary chlamydospore we observed in some Penicillia and even the ropy masses of mycelium are sometimes observed. However, the fruiting bodies are typically phomoid and the spores round or ellipsoid, and colored.

\section{MONILIACEAE}

3. CEPHALOSPÒRIUM CURTIPES Sacc.

Colonies floccose, white; hyphae creeping, septate, branched, reverse colorless; conidiophores short, arising as lateral branches of the mycelium, conidial heads round; conidia elongate, elliptical, hyaline, 8-10 × 3-4 $\mu$.

Isolated from room of asthmatic patient. Ponce. Oct. 10, 1945.

4. TRICHODERMA KONINGI Oud.

Colonies light green, reverse colorless, vegetative hyphae septate, hyaline, conidia elliptic, 3-4 × 2-3 $\mu$, smooth, hyaline.

Isolated from balcony in dwelling of B. Alzamora, Mayaguez, Sept., 1944. 5. TRICHODERMa ligNorum (Tode) Harz.

Colonies hyaline, fruiting areas in white tufts, reverse colorless; conidiophores forming whorls; conidia globose, smooth, 3-4 $\mu$ in diameter.

Isolated from dwelling of F. Bonin, Ponce. Oct. 1945.

6. ASPERGILLUS FLAVUS Link.

Conidial areas yellowish, reverse lighter; conidiophores with pitted walls; conidia pyriform, hyaline to yellow, usually rough, $2 \times 6 \mu$ in diameter. Sclerotia white. 
Isolated from dwelling of F. Bonin, Ponce. Oct. 1945.

*7. aspergillus flavipes Bainier and Sartory.

Colonies white at first; then yellowish. "Hulle" cells usually present. Reverse yellow to brown, heads columnar, light colored; conidia smooth.

Isolated from parlor at Alzamora's house. Sept. 1944, Mayaguez.

8. Aspergillus Niger van Tieghem.

Colonies submerged, yellowish. Reverse uncolored. Conidial heads black.

Isolated from Dr. R. Perea's house. Mayaguez, June 1944.

9. ASPERgILlus terReus Thom.

Colonies cinnamon, spreading, velvety. Reverse yellowish; heads long, up to $500 \mu$; conidia elliptic, smooth.

Isolated from balcony of B. Alzamora's house. Mayaguez, Sept. 1944. *10. AsPergilluUs LUCHUENSIS Inui.

Resembling in general character $A$. niger, but heads lighter in color.

Isolated from balcony of B. Alzamora's house, Mayaguez, Sept. 1944.

*11. aspergillus ochraceus Wilhelm.

Colonies ochraceous, with little mycelium. Conidiophores pitted with yellow; conidial heads globose, radiate; conidia spinulose, yellow.

Isolated from B. Castell's house. Playa Ponce, June 1944.

*12. aspergillus tamarir Kita.

Colonies greenish, reverse pinkish, head columnar, with radiating chains; phialides in two series; conidia pyriform, rough.

From Dr. R. Perea's house, Mayaguez, Sept. 1944.

*13. aspergilluus fumigatus Fres.

Colonies green to dark green; reverse yellowish; conidia dark green in mass, globose.

Isolated from parlor in home of B. Alzamora, Mayaguez, Sept. 1944. 14. PENICILlium CHRYSOGENUM Thon.

Colonies green, cottony, spreading; reverse yellow; conidiophores separate, about $300 \mu$ long; conidial heads about $200 \mu$; conidia elliptical or globose, $3-5 \mu$, pale green.

Isolated from Maldonado's home, Ponce. Oct. 1945.

15. PENICILLIUM CYCLOPIUM Westling.

Colonies in coremiform masses, loose, spreading, surface blue-green, reverse reddish; conidiophores intertwined; heads in columnar masses, about $350 \mu$ long; fructifications in three rows of metulae; conidia globose, smooth, $2-4 \mu$.

Isolated from M. Vallecilla house, Ponce. Oct. 1945.

16. PENICILLIUM.... . VIRIDICATUM Westling

Colonies velvety, green, reverse colorless, conidiophores about $200 \mu$ long; 
heads in loose, radiate masses; fructifications in three stages; conidia smooth, globose, light green, 3-4 $\mu$ diameter.

Isolated from B. Alzamora's house, Mayaguez. July 1944.

*17. PEnicillium expansum (Link) Thom.

Colonies gray green, brown with age, floccose, concentric; reverse brown, conidiophores singly; conidial fructifications in 3 series, 120-180 $\mu$ long; phialides crowded; conidia elliptical to globose, $2-4 \mu$ diameter, green.

Isolated from parlor of B. Alzamora's house, Mayaguez, July 1944. 18. PENICILlium RUGUlosum Thom.

Colonies yellowish-green, reverse yellow to orange, conidiophores about $200 \mu$; conidia elliptical, green, verrucose $3-4 \times 2.5 \mu$ diam.

Isolated from parlor of R. Perea's home, Mayaguez, June 1944. *19. scopulariopsis BRevicaulis Bainier.

Colonies white at first, then yellowish brown; conidiophores short; conidia in chains, pear-shaped, in mass light brown to chocolate, 6-8 $\times 7-9 \mu$.

Isolated from parlor of Maldonado's house, Ponce. Oct. 1945. 20. acrostalagmus cinnabarinus Corda.

Colonies round, orange to red; conidiophores terminating in branches bearing conidia; conidia oblong, 5-8 × 3-4 $\mu$; head enveloped by slime.

Isolated from Bauza's parlor, Ponce. Oct. 1945.

21. TRICHOTHECIUM ROSEUM Link.

Colonies white at first, then pink; conidiophores erect, conidia acrogenous, single; forming a head by the apical growth, cell larger, pear shaped, two celled, hyaline, 19-14 x 8-10 $\mu$.

Isolated from porch at Alzamora's house. Mayaguez, Sept. 1944.

\section{DEMATIACEAE}

\section{STACHybotrys alternans Bonorden}

Sterile hyaphae black brown; conidiophores erect, unbranched; conidia borne on phialides, elliptical, black, echinulate, $8-12 \times 5-8 \mu$.

Isolated from Maldonado's room. Ponce, Oct. 1945.

*23. HormodendRuM Cladosporioides (Fres) Sacc.

Colonies dark olivaceous, round, dense; conidiophores erect, branched, olivaceous at the apex; conidia cylindrical to oval, smooth, olivaceous, continuous or septate.

Isolated from sputum and bed-room of Tuti Alzamora, Mayaguez, June 1944.

24. Curvularia pilae sp. nov.

Hyphis sterilibus tenuibus, effusis, flexuosis nodulosisque, septatis atrofuscis; conidiophoris erectis rigidis fuscis; conidiis obtuse-fusoideis, 2-3 septatis, fuscis, loculo centrali obscuriore dilatati ibique plerumque abrupte geniculatis, loculis terminalibrus dilutioribus subhyalinis. 
Curvularia lunata (Walker) Boedjin valde affine, sed conidiis minoribus diversum.

Eximio medico portorricence Emmanueli Pila, sui libenter diccata.

In solutionibus cultum. B. Alzamora *4 (typus) Prope Mayaguez.

Mycelium septate, richly branched, subhyaline to dark brown; hyphae 3-7 $\mu$ wide, sometimes nodulose; conidiophores brown, septate, erect, unbranched, dark brown on the lower part, in the upper, lighter and pellucid, sometimes swollen and with knobs, lower cells $6 \mu$ wide, $8 \mu$ long, tip cells narrower, nearly round, $4 \mu$ in diameter, tips obtuse, 190-280 $\mu$ long; conidia borne in a whorl at the tip of the conidiophores, two to three septate, straight or curved, brown, end cells light colored, center cell darkbrown, 15-20 × 6-9 $\mu$, ends obtuse.

The genus Curvularia was established by Boedjin (Bull. Jard. Bot. Buitenzorg 13: 120, 1933) by segregating from Helminthosporium Link those species characterized by short, few septate conidia. In addition to the number of septa, a feature of the genus is the curved or bent character of the conidia, due to the growth of the central cell, which becomes larger and darker than the terminal cells. This makes the spores dark brown in the center and almost hyaline in the ends. This same character of the spores is a feature of some species of Spondylocladium Martius and Acrothecium Preuss. 